\title{
スキムミルクを主原料とする栄養成分を強化した 食品のラットにおけるミネラル生体利用性
}

\author{
加藤健, 鳥 羽保宏, 高田幸宏, 青 江 誠一郎 \\ 雪印乳業(株)栄養科学研究所 \\ Mineral Bioavailability of Fortified Food Based on \\ Skim Milk Powder in Rats \\ Ken Kato, Yasuhiro Toba, Yukihiro Takada and Seiichiro Aoe \\ Nutritional Science Laboratory, Snow Brand Milk Products Co., Ltd.
}

An investigation was conducted using adult female rats regarding mineral absorption and bioavailability (observed as increase of bone mineral contents and bone strength) of the food consisting basically of skim milk powder, fortified with calcium, vitamin D and collagen by comparing with $\mathrm{CaHPO}_{4}$, a fish bone powder, and an ordinary skim milk powder. No significant differences were found among the four groups in body weight gain, food intake or food efficiency. However, breaking force, breaking energy and calcium content of the femur in the fortified food group were significantly higher than those in the CaHPO4 group. Serum $1 \alpha, 25(\mathrm{OH})_{2} \mathrm{D}_{3}$ concentration and apparent mineral (calcium and phosphorus) absorption rates in the fortified food group were also higher than those in the other three groups.

These results indicate that enhanced strength of the bones observed in rats fed the fortified food may be mainly due to increased mineral absorption. It is concluded that the fortified food is a desirable foodstuff for better mineral bioavailability.

Jpn. J. Nutr., 55 (4) 189 196 (1997)

緒 言

我が国のカルシウム摂取量は、ここ 20 年横ばいの状態にあり，成人の栄盖所要量である 1 日 $600 \mathrm{mg}$ 摄取を 下回っている1”。また，近年の高齢化に伴い，骨粗韾症を始めとするカルシウムの摂取不足が主要因である疾 患の増加が大きな社会問題になっている。特に女性は, 男性に比べ最大骨量が低く, 閉経後の女性ホルモンの 分泌低下に伴って骨量が著しく減少するため, 骨粗短症の発生率が高くなっている2)。この場合, 吸収性に優 れた良質のカルシウムを含む牛乳，乳製品からカルシウムを摄取することが望ましいとされている ${ }^{3.4) 。 そ の ~}$ 中でも，特にスキムミルクは，脱脂されているため脂肪分が少なく，20 g で牛乳 1 本分のカルシウム（約 200 mg）を摄取できることから，良質のカルシウム供給源であるとされている5)。また，高齢者では，長年の食習 慣, 牛乳嫌いあるいは乳糖不耐症などの問題から, 牛乳そのものを摄取することが難しいため, スキムミルク

\footnotetext{
Key words : calcium bioavailability, skim milk powder, mineral, vitamin D, magnesium カルシウム生体利用性, スキムミルク, ミネラル, ビタミン D, マグネシウム
} 
を料理やおやつに取り入れ，カルシウムを補給することが よいと考えられている6。。このスキムミルクの骨に対する 有効性については，江澤によって報告されている7”。

一方, 最近では，牛乳，乳製品摂取の少ない日本人の食 生活に鑑み,カルシウムの摂取不足を補うために, 多くの カルシウム強化食品が開発され，市場に出回っている。こ れらのカルシウム強化食品には, 炭酸カルシウムやリン酸 カルシウムなどの無機態のカルシウム素材に加え，天然物 由来の牛骨粉や牛乳由来のカルシウム素材などが利用され ている。特に, 牛乳由来のカルシウム素材は, 他のカルシ

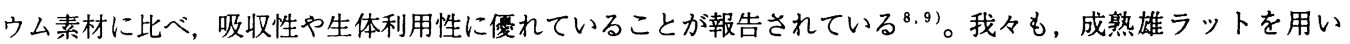
て, レンネットカゼインから調製したコロイド状及びカゼイン結合性カルシウムに富む乳カルシウム標品の吸 収性及び生体利用性が高いことを報告している ${ }^{10)}$ 。

また, ビタミンDは, カルシウムの代謝に極めて重要な作用を有し, 小腸上部でのカルシウム吸収促進作 用，並びに最近では，骨への直接作用を有することが知られている ${ }^{11} 。 一$ 般にビタミンDは，紫外線照射によっ て生体内で合成され，肝臟及び副甲状腺ホルモンの作用を伴って，腎臓で活性化され作用する。しかし，紫外 線照射の機会が少ない高齢者などでは，生体内でのビタミンDの合成が十分に行われないため，食事からの ビタミンD撖取が重要であると考えられている ${ }^{6.12) 。 ~}$

更にコラーゲンは，骨基質成分の $80 \%$ 以上を占めるたんぱく質で'13)，骨を形成する上で非常に重要であるこ とが知られている(14)。最近コラーゲンに培養軟骨細胞の増殖促進作用があることが報告され ${ }^{(6)}$ ，食事性の発醳 コラーゲンペプチドにはカルシウム吸収促進効果を介した骨形成促進作用があることが示唆されている ${ }^{16)} 。$

そこで, 良質のカルシウム供給源であるスキムミルクに, 生体利用性に優れた牛乳由来のカルシウム素材を 添加することによってカルシウムを強化し, 更に, ビタミンD 及びコラーゲンを配合した食品（栄養成分を 強化した食品）の成人女性に対する有效性を調べる目的で, 成熟雌ラットを用いて，そのミネラル吸収性及び ミネラル生体利用性（骨中ミネラル含量及び骨強度の増加として観察される）について検討した。

\section{実 験 方 法}

\section{1. 栄養成分を強化した食品の組成}

栄養成分を強化した食品は, 脱脂粉乳を主原料とし, 乳清由来のカルシウム素材（カルシウム含量 $16.3 \%$, リン含量 $10.0 \%$, マグネシウム含量 $1.0 \%$ ）で，カルシウムを強化した雪印乳業(株)製のものを用いた（商 品名 “自然にカルシウム”)。この栄養成分を強化した食品中に含まれる栄養成分の組成を Table 1 に示す。 なお，この栄養成分を強化した食品には，カルシウム，ビタミン D 及びコラーゲンが，各々 $100 \mathrm{~g}$ 当たり 2,000mg, $370 \mathrm{IU}$ 及び 1,680mg含まれていた（Table 1 )。また，この栄養成分を強化した食品並びに比較に用 いたスキムミルクには，活性型ビタミンDが各々 $100 \mathrm{~g}$ 当たり約 $1 \mathrm{IU}$ 含まれていた。

\section{2. 動物実験及び飼育方法}

実験動物には, 体重約 $250 \mathrm{~g}$ の 10 週歯 Sprague-Dawley 系雌ラット（日本チャールズリバー(株))を用い た。飼育は 12 時間ごとの明暗サイクルで行い, 飼料及び脱イオン水を自由摄取させた。 
実験飼料の組成を Table 2 に示す。実験飼料は AIN-93M 飼料組成 ${ }^{177}$ に従っ て調製し, 乳成分を全く含 まない大豆たんぱく質（フ ジプロ $\mathrm{R}$, フジピュリナプロ テイン(株))及びリン酸水素 カルシウム $\left(\mathrm{CaHPO}_{4}\right)$ から成る飼料を投与した群 を対照群とした。

対照群の飼料のカルシウ 么源 $(\mathrm{CaHPO})$ を, 魚骨 粉 (N-CaF タイプ, 白石 カルシウム(株))で置換し た飼料を投与した群を魚骨 粉群（Fish 群）とした。 なお, 魚骨粉は, あらかじ め $1,000^{\circ} \mathrm{C}$ で約 7 時間焼成 し，有機成分を除去したも のを用いた。

Fish 群の飼料にスキム ミルク（雪印乳業(株)）を $14 \%$ 添加し, 飼料中のカル シウムの約 $1 / 3$ をスキムミ ルク由来のカルシウムで置 換した飼料を投与した群を スキムミルク群 (Skim 群), また, Fish 群の飼料に栄 養成分を強化した食品を $8.4 \%$ 添加し, 飼料中のカ ルシウムの約 $1 / 3$ を栄盖成 分を強化した食品由来のカ
Table 2 Composition of diets

\begin{tabular}{|c|c|c|c|c|}
\hline \multirow[b]{2}{*}{ Compound } & \multicolumn{4}{|c|}{ Group } \\
\hline & Control & Fish & Skim & F-Food \\
\hline Soy protein isolate (\%) & 14 & 14 & 8 & 11.1 \\
\hline Fish bone powder & - & 1.31 & 0.87 & 0.87 \\
\hline Skim milk powder & - & - & 14 & - \\
\hline Fortified food & - & - & - & 8.4 \\
\hline Cornstarch & 46.5692 & 46.5692 & 46.5692 & 46.5692 \\
\hline Dextrinized cornstarch & 15.5 & 15.5 & 15.5 & 15.5 \\
\hline Sucrose & 10.271 & 10.667 & 3.659 & 5.836 \\
\hline Soybean oil & 4 & 4 & 4 & 4 \\
\hline Cellulose & 5 & 5 & 5 & 5 \\
\hline Vitamin mixture ${ }^{* 1}$ & 1 & 1 & 1 & 1 \\
\hline L-Cystine & 0.15 & 0.15 & 0.17 & 0.16 \\
\hline DL-Methionine & 0.25 & 0.25 & 0.14 & 0.2 \\
\hline Choline bitartrate & 0.25 & 0.25 & 0.25 & 0.25 \\
\hline Tert-butylhydroquinone & 0.0008 & 0.0008 & 0.0008 & 0.0008 \\
\hline $\mathrm{CaHPO}_{4} \cdot 2 \mathrm{H}_{2} \mathrm{O}$ & 2.104 & - & - & - \\
\hline $\mathrm{KH}_{2} \mathrm{PO}_{4}$ & - & 0.56 & 0.411 & 0.478 \\
\hline $\mathrm{NaH}_{2} \mathrm{PO}_{4} \cdot 2 \mathrm{H}_{2} \mathrm{O}$ & - & - & 0.141 & - \\
\hline $\mathrm{NaCl}$ & 0.018 & - & - & 0.062 \\
\hline $\mathrm{Na}_{2} \mathrm{CO}_{3}$ & 0.015 & 0.015 & - & - \\
\hline $\mathrm{K}_{2} \mathrm{SO}_{4}$ & 0.164 & 0.164 & - & 0.164 \\
\hline $\mathrm{K}_{2} \mathrm{CO}_{3}$ & 0.168 & - & - & - \\
\hline $\mathrm{MgO}$ & 0.068 & 0.014 & - & 0.027 \\
\hline $\mathrm{KCl}$ & 0.308 & 0.18 & - & 0.097 \\
\hline $\mathrm{MgCl}_{2} \cdot 6 \mathrm{H}_{2} \mathrm{O}$ & - & 0.206 & 0.012 & 0.122 \\
\hline $\mathrm{MgSO}_{4}$ & - & - & 0.113 & - \\
\hline Citric acid monohy & 0.064 & 0.064 & 0.064 & 0.064 \\
\hline Basal mineral mixture*2 & 0.1 & 0.1 & 0.1 & 0.1 \\
\hline
\end{tabular}

Analyzed Calcium (mg\%)

488

491

501

494
Phosphorus 492 Magnesium

47
470

45
534

*1 This was identical with AIN-93 vitamin mixture. *2 21.21 $\% \mathrm{FeC}_{6} \mathrm{H}_{5} \mathrm{O}_{7} \cdot \mathrm{xH}_{2} \mathrm{O}(\mathrm{x}=5), 5.775 \% \mathrm{ZnCO}_{3}, 2.205 \% \mathrm{MnCO}_{3}, 1.134$ $\% \mathrm{CuCO}_{3} \cdot \mathrm{Cu}(\mathrm{OH})_{2} \cdot \mathrm{H}_{2} \mathrm{O}, 35 \mathrm{mg} \% \mathrm{KIO}_{3}, 35.875 \mathrm{mg} \% \mathrm{NaSeO}_{4}, 27.825$ $\mathrm{mg} \%\left(\mathrm{NH}_{4}\right)_{6} \mathrm{Mo}_{7} \mathrm{O}_{24} \cdot 4 \mathrm{H}_{2} \mathrm{O}, 5.075 \% \mathrm{Na}_{2} \mathrm{SiO}_{3} \cdot 9 \mathrm{H}_{2} \mathrm{O}, 962.5 \mathrm{mg} \% \mathrm{CrK}$ $\left(\mathrm{SO}_{4}\right)_{2} \cdot 12 \mathrm{H}_{2} \mathrm{O}, 60.9 \mathrm{mg} \% \mathrm{LiCl}, 285.25 \mathrm{mg} \% \mathrm{H}_{3} \mathrm{BO}_{3}, 222.25 \mathrm{mg} \% \mathrm{NaF}$, $107.1 \mathrm{mg} \% \mathrm{NiCO}_{3} \cdot 2 \mathrm{Ni}(\mathrm{OH})_{2} \cdot 4 \mathrm{H}_{2} \mathrm{O}, 23.1 \mathrm{mg} \% \mathrm{NH}_{4} \mathrm{VO}_{3}$.

ルシウムで置換した飼料を投与した群を，栄養成分を強化した食品群（F-Food 群）とした。

なお, カルシウム給源のパターンは, 我が国において, 乳及び乳製品がカルシウム供給源として寄与してい る割合 ${ }^{18)}$ を考慮して決定した。また，栄養成分を強化した食品を添加したF-Food 群の飼料中ビタミンD含 量は, $100 \mathrm{~g}$ 当たり $130 \mathrm{IU}$ で, 対照群, Fish 群及びSkim 群の約 1.3 倍であった。一方, 各群飼料中の活性 型ビタミンD含量は，いずれも検出限界 $(0.151 \mathrm{IU} / 100 \mathrm{~g})$ 以下であった。更に，各群飼料中の粗たんぱく 
質含量, 含硫アミノ酸含量及 びミネラル含量（カルシウム $0.50 \%$, リン $0.50 \%$ ，マグ ネシウム $0.05 \%$ ）は同様に なるように調整した。

ラットは, 1 群 10 匹ずつ 上記に示した実験飼料投与群 （4群）に分け，31日間飼育 した。実験飼料投与開始時 （10 週歯時）及び投与開始か
Table 3 Body weight gain, food inteke and food efficiency

$(\mathrm{M} \pm \mathrm{SD})$

\begin{tabular}{lccc}
\hline Group & $\begin{array}{c}\text { Body weight gain } \\
\text { ( g/day) }\end{array}$ & $\begin{array}{c}\text { Food intake } \\
\text { (g/day) }\end{array}$ & $\begin{array}{c}\text { Food efficiency*1 } \\
(\%)\end{array}$ \\
\hline Control & $0.63 \pm 0.44$ & $16.87 \pm 1.49$ & $3.70 \pm 2.41$ \\
Fish & $0.83 \pm 0.31$ & $17.53 \pm 1.40$ & $4.82 \pm 1.76$ \\
Skim & $0.94 \pm 0.32$ & $18.09 \pm 1.17$ & $5.30 \pm 1.62$ \\
F-Food & $0.94 \pm 0.32$ & $17.63 \pm 1.60$ & $5.43 \pm 1.56$
\end{tabular}

*1 Food efficiency $(\%)=$ (final body weight $(\mathrm{g})$ - initial body weight $(\mathrm{g})$ ) /food intake ( $\mathrm{g} / 31$ days $) \times 100$.

ら 21 日後 (13 週齡時) に, 各群のラットを代謝ケージに入れて 3 日間馴化した後, 各々 4 日間の飼料摂取量 及び䔬排泄量を測定した。試験終了後，エーテル麻酔下で開腹し，下行大静脈より採血して血清を分離した。 採血後，左右大腿骨を摘出した。

\section{3. 測定方法}

(1) 見かけのミネラル吸収率の測定

10 週齢時及び 13 週齢時に採取した䔬中に排泄されたミネラル（カルシウム, リン及びマグネシウム）の量 は，粪表面に付着した飼料及び毛を脱イオン水で除去し，凍結乾燥後コーヒーミルで粉砕し，乾式灰化して ICP 発光分析装置（PS-3000UV, LEEMAN LABS 社製）にて定量し，兾排泄量から求めた。

ミネラル摂取量及び䔬中ミネラル排泄量から以下に示す式を用いて，見かけのミネラル吸収率を算出した。

見かけのミネラル吸収率 $(\%)=($ ミネラル摂取量一䔬中ミネラル排泄量) /ミネラル摄取量 $\times 100$

(2) 血清中 $1 \alpha, 25(\mathrm{OH})_{2} \mathrm{D}_{3}$ 濃度の測定

ラット血清中の $1 \alpha, 25(\mathrm{OH})_{2} \mathrm{D}_{3}$ 濃度は， $\mathrm{C}_{18}$ Sep-Pak カラム (Waters 社製)による血清中 $1 \alpha, 25(\mathrm{OH})_{2}$ $\mathrm{D}_{3}$ 画分の抽出と, ウシ胸腺レセプター (ヤマサ将油(株)) を使用したラジオレセプターアッセイを組み合わ せた方法により測定した ${ }^{19,20)}$ 。

（3）大腿骨破断強度及び大腿骨ミネラル含量の測定

左右大腿骨の破断強度は, 骨破断強度測定装置（レオロメーターRX-1600，アイテクノ社製）で測定した。 その後, 大腿骨を凍結乾燥し, 重量を測定して乾式灰化後, ICP 発光分析装置にて大腿骨ミネラル含量を測 定した。

(4) 実験結果の統計処理

動物実験に関する全てのパラメータの統計処理は，一元配置の分散分析を行った後，Tukey-Kramer 法に て多重比較を行った。

\section{実 験 結 果}

(1) 体重増加量，飼料摂取量及び飼料効率

体重增加量, 飼料摄取量及び飼料効率を Table 3 に示した。いずれのパラメータとも4 群間に差は認めら れず，成育状態は全て良好であった。 
Table 4 Apparent absorption rate of calcium, phosphorus and magnesium in 10- and 13-week-old rats

\begin{tabular}{lcc}
\hline Group & 10 -week-old & 13 -week-old \\
\hline$\langle$ Apparent calcium absorption rate〉 & & \\
Control & $31.74 \pm 3.69^{\mathrm{a}}$ & $20.04 \pm 2.33^{\mathrm{a}}$ \\
Fish & $30.03 \pm 4.87^{\mathrm{a}}$ & $19.06 \pm 4.55^{\mathrm{a}}$ \\
Skim & $30.26 \pm 8.32^{\mathrm{a}}$ & $17.94 \pm 7.29^{\mathrm{a}}$ \\
F-Food & $35.76 \pm 3.81^{\mathrm{a}}$ & $24.18 \pm 3.61^{\mathrm{a}}$ \\
\hline$\langle$ Apparent phosphorus absorption rate〉 & & \\
Control & $48.09 \pm 3.41^{\mathrm{a}}$ & $40.21 \pm 2.31^{\mathrm{a}}$ \\
Fish & $55.87 \pm 3.10^{\mathrm{b}}$ & $47.14 \pm 3.30^{\mathrm{b}}$ \\
Skim & $55.07 \pm 4.66^{\mathrm{b}}$ & $47.10 \pm 5.14^{\mathrm{b}}$ \\
F-Food $^{\mathrm{b}}$ & $57.72 \pm 2.81^{\mathrm{b}}$ & $49.27 \pm 2.72^{\mathrm{b}}$ \\
\hline$\langle$ Apparent magnesium absorption rate〉 & & \\
Control & $42.05 \pm 5.47^{\mathrm{a}}$ & $34.47 \pm 6.01^{\mathrm{a}}$ \\
Fish & $45.93 \pm 7.50^{\mathrm{a}}$ & $36.33 \pm 6.25^{\mathrm{a}}$ \\
Skim & $46.08 \pm 7.55^{\mathrm{a}}$ & $40.06 \pm 7.96^{\mathrm{a}}$ \\
F-Food $^{\mathrm{a}}$ & $48.78 \pm 4.06^{\mathrm{a}}$ & $41.51 \pm 5.49^{\mathrm{a}}$ \\
\hline
\end{tabular}

a,b Values in the same column with different superscript letters are significantly different $(p<0.05)$.

(2) 見かけのミネラル吸収率

見かけのカルシウム及びマグネシウム吸収 率には，統計学的な有意差は認められなかっ た。しかし，13 週齢時の見かけのカルシウ ム吸収率は，F-Food 群が他の群に比べ高 い傾向を示した $(p=0.08$, Table 4$)$ 。また, 見かけのリン吸収率は, 対照群に比べ他の 3 群で 10 週齢時, 13 週齢時とも有意に高い値 を示し、F-Food 群で最も高い值を示した (Table 4 )。

（3）血清中 $1 \alpha, 25(\mathrm{OH})_{2} \mathrm{D}_{3}$ 濃度 血清中 $1 \alpha, 25(\mathrm{OH})_{2} \mathrm{D}_{3}$ 濃度は, Fig. 1 に示したように，対照群及びFish 群に比べ, F-Food 群で有意に高い値を示した。

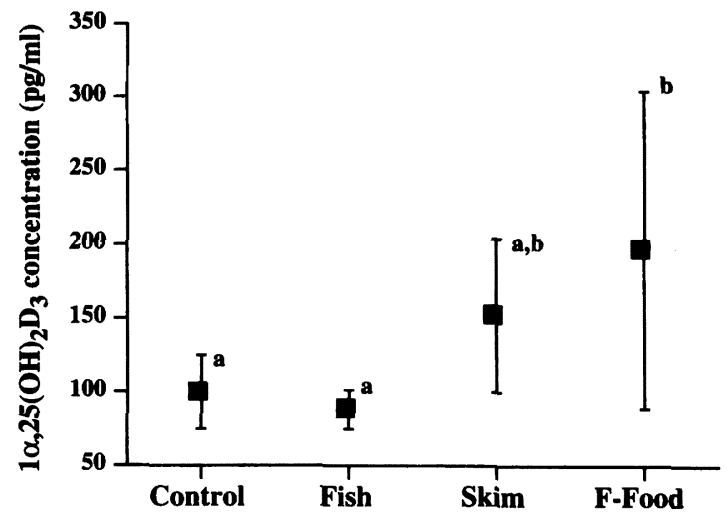

Fig. 1 Effect of experimental diets on serum $1 \alpha$, $25(\mathrm{OH})_{2} \mathrm{D}_{3}$ concentration in 14 -week-old rats

Bars represent $95 \%$ confidence intervals. .0 Values with different superscript letters are significantly different $(p<$ $0.05)$.

（4）大腿骨破断強度及び大腿骨ミネラル含量

大腿骨破断応力及び大腿骨破断エネルギーは, F-Food 群が対照群に比べ有意に高い值を示した（Fig. 2)。 また, 大腿骨の乾燥重量には 4 群間で差は認められなかったが, 大腿骨のカルシウム含量は, F-Food 群が 对照群及び Fish 群に比べ有意に高い値を示し，大腿骨のマグネシウム含量は，Skim 群及び F-Food 群が対 照群に比べ有意に高い値を示した（Table 5 )。一方，大腿骨のリン含量には，4群間に差は認められなかっ た。 
Table 5 Femur dry weight, femur calcium ( $\mathrm{Ca}$ ) content, femur phosphorus (P) content and femur magnesium $(\mathrm{Mg})$ content in 14-week-old rats

$(\mathrm{M} \pm \mathrm{SD})$

\begin{tabular}{lrrrr}
\hline & \multicolumn{4}{c}{ Group } \\
\cline { 2 - 5 } & \multicolumn{1}{c}{ Control } & Fish & Skim & F-Food \\
\hline Femur dry weight (mg) & $554.2 \pm 18.5^{\mathrm{a}}$ & $547.2 \pm 28.3^{\mathrm{a}}$ & $568.1 \pm 49.7^{\mathrm{a}}$ & $574.3 \pm 25.6^{\mathrm{a}}$ \\
Femur Ca content (mg/bone) & $132.8 \pm 4.2^{\mathrm{a}}$ & $130.7 \pm 7.5^{\mathrm{a}}$ & $138.9 \pm 9.7^{\mathrm{a}, \mathrm{b}}$ & $142.9 \pm 7.8^{\mathrm{b}}$ \\
Femur P content (mg/bone) & $63.5 \pm 2.3^{\mathrm{a}}$ & $64.1 \pm 3.3^{\mathrm{a}}$ & $64.9 \pm 5.6^{\mathrm{a}}$ & $65.8 \pm 3.6^{\mathrm{a}}$ \\
Femur Mg content (mg/bone) & $2.6 \pm 0.1^{\mathrm{a}}$ & $2.7 \pm 0.3^{\mathrm{a}, \mathrm{b}}$ & $2.8 \pm 0.2^{\mathrm{b}}$ & $2.8 \pm 0.2^{\mathrm{b}}$ \\
\hline
\end{tabular}

a.b Values in the same row with different superscript letters are significantly different $(p<0.05)$.

\section{考察}

本研究では，スキムミルクを主原料と

し,カルシウム, ビタミンD 及びコラー ゲンを配合し調製した食品（栄養成分を 強化した食品）の，健康な成人女性に対 する有効性を評価するため, 10 週齢の 成熟雌ラットを用いて検討した。なお， 本研究では, ミネラルの吸収性と生体利 用性を区別して考え，大腿骨へのミネラ ル沈着度並びに大腿骨の破断強度をミネ ラル生体利用性の指標とした。また本実 験では, 対照群及び Fish 群は, 乳また は乳製品を全く摂取せず，各々，一般的 なカルシウム素材である $\mathrm{CaHPO}_{4}$ から カルシウムを㠌取するモデル，及び我が 国古来の主要なカルシウム供給源である

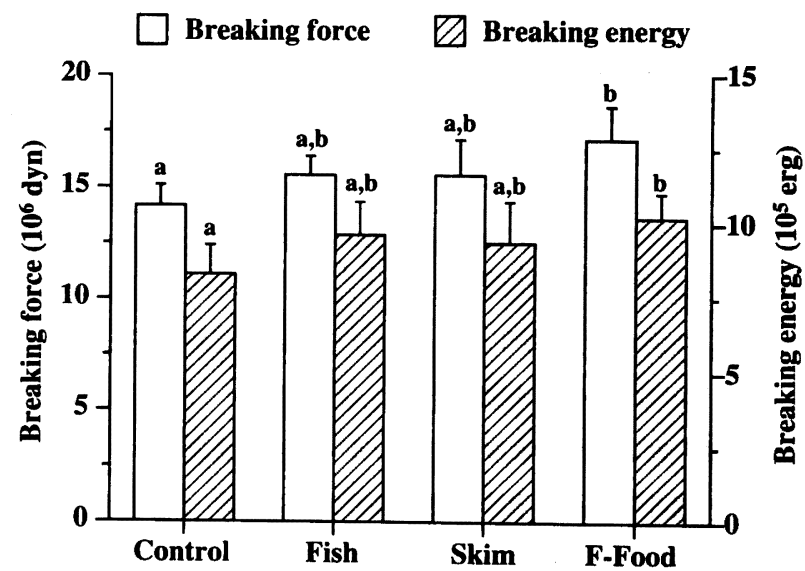

Fig. 2 Effect of experimental diets on breaking force and breaking energy of femur in 14-week-old rats

Bars represent $95 \%$ confidence intervals. a.b Values with different superscript letters are significantly different in breaking force and breaking energy $(p<0.05)$.

魚のみからカルシウムを摂取するモデルとして設定した。更に江澤は, 我が国において乳及び乳製品がカルシ ウム供給源として寄与している割合は $24 \%$ 程度であると報告している ${ }^{18)}$ 。そこで, Skim 群及び F-Food 群 では, Fish 群のカルシウムの約 $1 / 3$ を各々，スキムミルク由来のカルシウム及び栄養成分を強化した食品由 来のカルシウムで置換し, 比較検討した。

大腿骨の破断応力及び破断エネルギーの結果より，栄養成分を強化した食品は，骨強度の増加に有効である ことが示された。骨は，その約 70\%を占める骨塩と約 30\%を占める骨基質から成り立っている 骨強度の増加は，骨塩量と骨基質量の両者，あるいは一方の増加によるものと考えられる。本実験ではテータ は示さなかったが，骨基質の主要な構成成分であるコラーゲンに特徵的なアミノ酸であるハイドロキシプロリ ン及びハイドロキシリジンの大腿骨中の含量には，4群間で差は認められなかった。一方，大腿骨中カルシウ ム含量は、F-Food 群が有意に高い值を示した。このことから，栄養成分を強化した食品による骨強度の增 加は，主に骨塩量の増加によるものと考えられる。 
血清中の $1 \alpha, 25(\mathrm{OH})_{2} \mathrm{D}_{3}$ 濃度は, F-Food 群が対照群や Fish 群に比べ有意に高い值を示し，各ミネラ ル吸収率もF-Food 群が高值を示した。このことから，F-Food 群で認められた大腿骨中のミネラル含量の 増加には，栄養成分を強化した食品に配合されたビタミンDが体内で活性化され，ミネラル吸収促進的に作 用したことも寄与していると考えられる。

また, スキムミルク中のカルシウムは生体利用性に優れ”，更に牛乳由来のカルシウム素材は他のカルシウ ム素材に比べ，吸収性及び生体利用性に優れていることが報告されている ${ }^{8-10}$ 。従って，栄養成分を強化した 食品の投与による大腿骨ミネラル含量の増加には，この生体利用性に優れた牛乳由来のカルシウムも関与して いると考えられる。

今回の実験系では，栄盖成分を強化した食品に配合されているコラーゲンの有効性については明らかにでき なかった。しかし，これまでコラーゲンには，培養軟骨細胞の増殖を促進する作用 ${ }^{15)}$ や，消化管内で生理活性 ペプチドを生成する可能性 ${ }^{(4)}$ が報告されており，また，食事性の発酵コラーゲンペプチドには，骨形成促進作 用があることが示唆16)されていることから，今回の実験でも、ビタミンDや牛乳由来のカルシウムとともに， 骨に対して何らかの影響を及ほした可能性も考えられる。コラーゲンの骨に対する詳細な有効性については今 後の研究が待たれる。

また，今回の実験では，栄盖成分を強化した食品の投与によって，見かけのリン吸収率が高値を示した。一 般に，リンの吸収が立進している場合には，腎臓への影響が危惧される。しかし，今回の実験で用いたラット の腎臓には，肉眼的所見による石灰化等の異常は観察されなかった。

今後は，ヒトでの有効性並びに栄養成分を強化した食品に配合されている個々の成分の有効性及び相乗作用, 更に，栄養成分を強化した食品の損取が腎臓に与える影響について，詳細に検討することが必要であると考え られる。

\section{要 約}

本研究では，成熟雌ラットを用いて，スキムミルクを主原料とし，カルシウム，ビタミン D 及びコラーゲ ンを配合し調製した食品（栄養成分を強化した食品）の，ミネラル吸収性及びミネラル生体利用性（骨中ミネ ラル含量及び骨強度の増加として観察される）を，リン酸水素カルシウム，魚骨粉及び従来のスキムミルクと 比較検討した。

体重增加量, 飼料摄取量及び飼料効率は，4群間に差は認められなかった。しかし, 大腿骨破断応力, 大腿 骨破断エネルギー及び大腿骨中カルシウム含量は, 栄養成分を強化した食品投与群で, リン酸水素カルシウム 投与群に比べ有意に高い值を示した。更に，血清中の $1 \alpha, 25(\mathrm{OH})_{2} \mathrm{D}_{3}$ 濃度や見かけのミネラル（カルシウ ム、リン) 吸収率も，栄養成分を強化した食品の投与によって高値を示した。

以上の結果から，栄養成分を強化した食品には，骨強度を増加させる作用があることが認められ，その作用 は，主にミネラル吸収促進作用によるものであることが示唆された。従って，栄養成分を強化した食品は，ミ ネラル生体利用性に優れた食素材であると考えられる。

$$
\text { 文献 }
$$

1) 厚生省保健医療局健康增進栄養課：平成 6 年国民栄養調査結果の概要, 栄養学雑誌, 54, 205～220 (1996) 
2）江澤郁子：骨粗籍症予防対策一食生活と生活活動一，ビフィズス，7，13〜20（1993）

3）兼松重幸：成人における各種食品中のカルシウムの利用亚にカルシウム所要量に関する研究，栄着と 食糧, 6, 135 1 147 (1953)

4 ）上西一弘, 江澤郁子, 梶本雅俊, 土屋文安: 日本人の通常食における牛乳・小魚・野菜のカルシウム の吸収率の比較検討, 第 50 回日本栄養·食糧学会大会講演要旨集, p. 226 (1996)

5）江澤郁子：骨粗しょう症と食品, 月刊フードケミカル，1，42４6（1994）

6 ）江澤郁子：(1)栄養と運動で防ぐ骨粗㯏症, 臨床栄養, 88, 5 8 (1996)

7 ）江澤郁子 : 去勢雌ラットの大腿骨骨折に及ほすミルクの効果, 家政学雑誌，32，37４0（1981）

8 ）五十嵐千恵, 江澤郁子, 尾形悦郎：卵巣摘出骨粗蓼症モデルラットの骨塩減少に対する乳清カルシウ 厶の抑制効果，日本栄羡・食糧学会誌，43，437４43（1990）

9）五十嵐千恵, 江澤郁子：卵巣摘出骨粗鉝症モデルラットの大腿骨に対するWhey Calcium および Lactulose の骨強度增強効果, 応用薬理, 42, 245 253（1991）

10）加藤 健, 高田幸宏, 松山博昭, 青江誠一郎, 坂本隆男, 八尋政利, 中島一郎 : レンネットカゼイン から調製した乳カルシウム標品のラットにおける生体利用性, 日本栄養・食糧学会誌， $47,385 ３ 90$ (1994)

11）杉本利嗣：骨内ビタミンD 活性化の意義, Clinical Calcium，5，1165 1168（1995）

12）江澤郁子：骨粗䊝症の食事療法、ホルモンと臨床，43，823～828（1995）

13）日本生化学会編：生化学データブック, p. 1650 (1979) 東京化学同人, 東京

14）藤本大三郎：コラーゲンの機能と食品としての利用，食品と開発，31，13～15（1996）

15) Pesakova, V., Stol, M. and Adam, M. : Comparison of the influence of gelatine and collagen substrates on growth of chondrocytes, Folia Biologica (Praha), 36, 264 270 (1990)

16）暒原葉子：発酵コラーゲンペプチドの特性と利用，食品と科学，39，95９9（1997）

17) Philip, G. R., Forrest, H. N. and George, C. F. Jr. : AIN-93 purified diets for laboratory rodents: Final report of the American Institute of Nutrition Ad Hoc Writing Committee on the reformulation of the AIN-76A rodent diet, J. Nutr., 123, 1939 1951 (1993)

18）江澤郁子：カルシウム摂取量, Clinical Calcium, 2, 81 83（1992）

19) Reinhard, T. A., Horst, R. L., Orf, J. H. and Hollis, B. W. : A microassay for 1,25dihydroxy vitamin $\mathrm{D}$ not requiring high performance liquid chromatography : Application to clinical studies, J. Clin. Endocrinol. Metab., 58, 91 98 (1984)

20） 久保俊英, 田中弘之, 守分 正, 神崎 晋, 桶口譲二, 渡辺幸彦, 市川雅常, 山岡完次, 清野佳紀 : non-HPLC 法による 1,25 (OH $)_{2} \mathrm{D}$ 測定法，ホルモンと臨床，40，943９49 (1992)

（受付: 平成 8 年 11 月 15 日） 